Bangladesh Journal of Anatomy January 2013, Vol. 11 No. 1 pp 25-29

\title{
Variation in Weight of the Human Pituitary Gland in Different Age \& Sex
}

\author{
Mushfika Rahman', Shamim Ara², Farhana Akter ${ }^{3}$, Halima Afroz ${ }^{4}$, Anjuman Ara Sultana ${ }^{5}$, Abul \\ Kalam Mohammad Yousuf ${ }^{6}$, Jesmin Akhter ${ }^{7}$
}

\begin{abstract}
:
Contrext: The pituitary gland produces several hormones that regulate growth, metabolism and reproduction. Deviations from the normal functions of the gland certainly derange the harmony of life. Therefore, this study is important to identify variation in the weight of human pituitary gland in relation to age and sex.
\end{abstract}

Materials \& Methods: A cross-sectional analytical type of study was conducted in the department of Anatomy, Dhaka Medical College, on sixty (40 of male and 20 of female) human pituitary glands were collected from unclaimed dead bodies that were under examination in the morgue of department of Forensic Medicine, Dhaka Medical College, Dhaka.

The samples were divided into four groups. i.e. Group-A (20-29 years), Group-B (30-39 years), Group-C (40-49 years) and Group-D (50-59 years). The weight of the gland with the stalk was measured by means of a digital electric balance.

Results: In male the mean $\pm S D$ weight of the pituitary gland was found $355.56 \pm 49.78,261.18 \pm 52.31$, $244.44 \pm 51.26$ and $210 \pm 18.71 \mathrm{mg}$ in group $A, B, C$ and $D$ respectively. In female the mean $\pm S D$ weight was $381.11 \pm 14.53 \mathrm{mg}, 345 \pm 19.27 \mathrm{mg}$ and $313.33 \pm 11.53 \mathrm{mg}$ in group $A, B$, and $C$ respectively.

Conclusion: The weight of the pituitary gland showed gradual decreasing values with advancing age. The mean $\pm S D$ weight of male gland in this study was significantly lower than that of female glands.

Key Word: Weight, pituitary gland

\section{Introduction:}

The pituitary gland (hypophysis cerebri) is a reddish grey, ovoid body lies within the hypophyseal fossa of the sphenoid bone, covered superiorly by diaphragma sellae, which is pierced centrally by an

1. Assistant Professor. Department of Anatomy, Dr. Sirajul Islam Medical College, Dhaka.

2. Professor \& Head, Department of Anatomy, Dhaka Medical College, Dhaka.

3. Senior Lecturer, Department of Anatomy, Dhaka National Medical College, Dhaka.

4. Assistant Professor. Department of Anatomy, Green Life Medical College, Dhaka.

5. Lecturer, Department of Anatomy, Shaheed Suhrawardy Medical College, Dhaka.

6. Assistant Professor, Department of Pharmacology, Northern International Medical College, Dhaka.

7. Assistant Professor, Department of Biochemistry, Dr. Sirajul Islam Medical College, Dhaka.

Correspondence: Dr. Mushfika Rahman aperture for the infundibulum ${ }^{1}$. It is attached to the hypothalamic region of the brain by a narrow stalk and has both neural and vascular connections with the brain ${ }^{2}$. Structurally the gland is divided into a larger anterior region (adenohypophysis) and a smaller posterior region (neurohypophysis). They differ in development, types, arrangement of cells, their vascular and neural supplies. ${ }^{1}$ Physiologically adenohypophysis is important, as it produces hormones that regulate growth, metabolism and reproduction ${ }^{3}$. The pituitary secretes at least nine hormones, they stimulate the secretion of other endocrine glands e.g. thyroid, adrenal cortex and gonads. ${ }^{4}$ If the activity of hypophysis decreases, the patient suffers greatly from reduced activity of the thyroid gland, the gonads and the adrenal cortex. ${ }^{5}$ The gland measures about $12 \mathrm{~mm}$ in 
transverse and $8 \mathrm{~mm}$ in antero-posterior diameter and weighs about $500 \mathrm{mg}^{1}$. Dynamic changes occur in the size, shape and signal intensity of the pituitary gland during life ${ }^{6}$. These changes reflect the complex hormonal environment of the gland and are most pronounced at times of hormonal flux, such as menarche and pregnancy ${ }^{6}$. A radiological study conducted in London by McLachlan et al. in 1968, showed sex differences in weight of the gland. In a random postmortem sample (50 adults, male-23 and female-27 in number) - the gland was larger in females than males ${ }^{7}$. Rasmussen (1928;1934) conducted a study on American population, where the mean gland weight of women $(n=33)$ was more than that of men $(n=47)$ aged over 50 years . Erdheim and Stumme (1909) established in their study that increased gland size in females is mainly due to post pregnancies. In 22 multipara dying at term or within one week of delivery, mean gland weight was $1,070 \mathrm{mg}$ and in 13 multipara dying one to seven weeks postpartum, the mean weight was $788 \mathrm{mg}$. Thereafter the gland diminishes in weight 7 . The gland weighs approximately $800 \mathrm{mg}$ in the parous female 8 \& 9 . The weight of the gland usually varies according to activity ${ }^{10}$. The average weight of pituitary gland in men is about 500 to $700 \mathrm{mg}$, being slightly heavier in non-pregnant women and much heavier in pregnant women ${ }^{11}$. In females during or after pregnancy, the weight of the gland can be reached up to $1 \mathrm{gm}^{12}$. Pituitary adenomas are indolent tumors, which accounts for $10-15 \%$ of all diagnosed intracranial neoplasms ${ }^{13}$. A prospective cross sectional study in the Northern part of Bangladesh reveals that, the prevalence of hyperprolactinemia accounts for about $43 \%$ and $21 \%$ of primary and secondary infertility respectively 14. Prolactinomas are accounting for about $60 \%$ of primary pituitary tumors ${ }^{15}$. The second most common type is somatotrophic adenoma - which is characterized by elevated level of growth hormoneresults in gigantism and acromegaly before and after closure of epiphysis respectively ${ }^{16}$. About $25 \%$ of patients have diabetes insipidus ${ }^{12}$.

\section{Materials:}

The present study was performed on 60 (sixty) post mortem human pituitary glands of different age groups, of which 40 (forty) were males and 20 (twenty) females. Among them, the lowest age was 22 years in both sexes and the highest age was 55 years (male) and 45 years (female).

These entire samples were collected from the whole brains of the unclaimed dead bodies that were under examination in the Department of Forensic Medicine of Dhaka Medical College, Dhaka.

\section{Methods:}

Place and duration of study: This study was carried out in the Department of Anatomy, Dhaka Medical College, Dhaka, Bangladesh, from July 2009 to June 2010.

Grouping of the samples: The samples were divided into four groups by decade into age group $A$ (20-29 years), group B (30- 39 years), group C (4049 years) and group $D(50-59 \text { years })^{17}$. Detailed grouping and distribution of samples for morphological study were shown in Table-I.

Table- I

Grouping of the samples

\begin{tabular}{lccc}
\hline Group & Age in years & \multicolumn{2}{c}{ Number of samples } \\
\cline { 3 - 4 } & & Male & Female \\
\hline & A20-29 & 09 & 09 \\
B & $30-39$ & 17 & 08 \\
C & $40-49$ & 09 & 03 \\
D & $50-59$ & 05 & 00 \\
\hline
\end{tabular}

Measurement of weight:

Immediately after collection, the surface of each pituitary gland was dried with a blotting paper. Then the weight of the gland with the stalk was measured by means of a digital electric balance (Sartorius TE212, made in Germany) in grams. Then the weight in grams were converted to milligrams by multiplying with 1000 .

\section{Ethical Clearance:}

This study was approved by Ethical Review Committee of Dhaka Medical College, Dhaka 
Results:

Results are shown in the Table-II, Figure- 1.

Table - II

Weight of male \& female pituitary gland in different age groups

\begin{tabular}{lcccc}
\hline \multicolumn{1}{c}{ Group } \\
(Age in years $)$ & $\begin{array}{c}\text { Number } \\
(\mathrm{n})\end{array}$ & $\begin{array}{c}\text { Weight }(\mathrm{mg}) \text { of } \\
\text { Male gland } \\
\text { Mean } \pm \text { SD }\end{array}$ & $\begin{array}{c}\text { Weight }(\mathrm{mg}) \text { of } \\
\text { Female gland } \\
\text { Mean } \pm \text { SD }\end{array}$ & $\begin{array}{c}\text { Weight }(\mathrm{mg}) \\
\text { Both sex } \\
\text { Mean } \pm \text { SD }\end{array}$ \\
\hline A & $\mathrm{M}=9$ & $355.56 \pm 49.78$ & $381.11 \pm 14.53$ & $368.33 \pm 32.92$ \\
$(20-29)$ & $\mathrm{F}=9$ & $(280-470)$ & $(360-410)$ & $(280-470)$ \\
$B$ & $\mathrm{M}=17$ & $261.18 \pm 52.31$ & $345 \pm 19.27$ & $288 \pm 59.37$ \\
$(30-39)$ & $\mathrm{F}=8$ & $(180-330)$ & $(320-370)$ & $(180-370)$ \\
C & $\mathrm{M}=9$ & $244.44 \pm 51.26$ & $313.33 \pm 11.53$ & $261.67 \pm 53.91$ \\
$(40-49)$ & $\mathrm{F}=3$ & $(190-350)$ & $(300-340)$ & $(190-350)$ \\
$D$ & $\mathrm{M}=5$ & $210 \pm 18.71$ & - & $210 \pm 18.71$ \\
$(50-59)$ & $\mathrm{F}=0$ & $(180-230)$ & & $(180-230)$ \\
\hline
\end{tabular}

Figure in parenthesis indicates range. During statistical analysis, comparison between the sex was done by unpaired student's ' $\mathrm{t}$ ' test and in between different age group. Comparison was done by One way ANOVA.

$\mathrm{P}>0.05^{\mathrm{ns} ;}$ Weight between male \& female gland in group $\mathrm{A}$.

$\mathrm{P}<0.01^{* * *} ;$ Weight between male \& female gland in group $\mathrm{B}$.

$P<0.01^{* *}$; Weight between male \& female gland in group $C$.

$P<0.01^{* *}$; Weight between group $A \& B, A \& C, A \& D, B \& D$

$P>0.01 \mathrm{~ns} ;$ Weight between group $B \& C$ and $C \& D$.

Note: $\mathrm{n}=$ Number of samples, $\mathrm{SD}=$ Standard deviation, $\mathrm{ns}=$ not significant, ${ }^{* *} /{ }^{* * *}=$ significant.

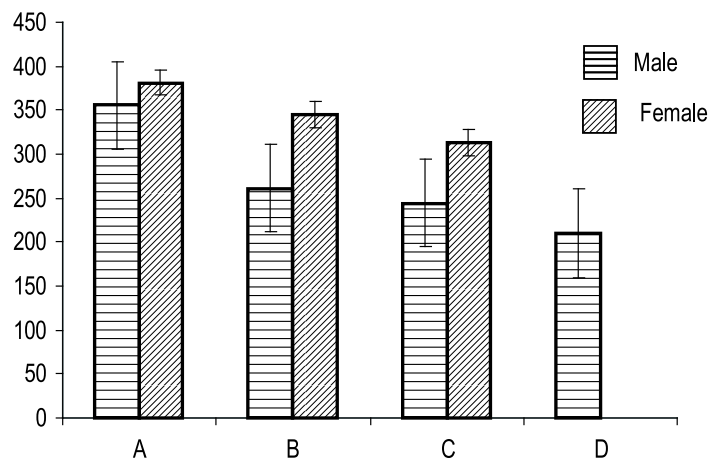

Fig.-1 : Bar diagram showing weight of the pituitary gland in male and female in different age groups.

The mean \pm SD of weight of the pituitary gland was found $355.56 \pm 49.78,261.18 \pm 52.31,244.44 \pm$ 51.26 and $210 \pm 18.71 \mathrm{mg}$ in male samples of group $A, B, C$ and $D$ respectively. In female the mean \pm SD of weight was $381.11 \pm 14.53 \mathrm{mg}, 345 \pm 19.27$ $\mathrm{mg}$ and $313.33 \pm 11.53 \mathrm{mg}$ in group $\mathrm{A}, \mathrm{B}$, and $\mathrm{C}$ respectively. Significant differences were observed in mean $\pm S D$ of weight in between male and female in both group $B(P<0.01)$ and group $C(P<0.01)$ (Table II).

The mean \pm SD of weight of the pituitary gland was $368.33 \pm 32.92,288 \pm 59.37,261.67 \pm 53.91$ and $210 \pm 18.71 \mathrm{mg}$ in group $A, B, C$ and $D$ respectively. The highest weight was found in group $A$ and the lowest one was found in group D. Significant differences were found in mean $\pm S D$ of weight in between group $A$ and $B(P<0.01)$, group $A$ and $C(P$ $<0.01)$, group $A$ and $D(P<0.01)$ and group $B$ and $\mathrm{D}(\mathrm{P}<0.01)$ (Table II).

\section{Discussion:}

In the present study, the mean \pm SD of weight of the pituitary gland was found to be $368.33 \pm 32.92 \mathrm{mg}$ in group $A, 288 \pm 59.37 \mathrm{mg}$ in group $B, 261.67 \pm$ 
$53.91 \mathrm{mg}$ in group $C$ and $210 \pm 18.71 \mathrm{mg}$ in group $D$ which was smaller to all the values that were found in texts or other literatures. The pituitary gland weighs about $500 \mathrm{mg}$ in adults stated by Rogers and Jacob ${ }^{5}$, Fawcett ${ }^{18}$, Gartner and Hiatt ${ }^{3}$, Thibodeau and Patton ${ }^{19}$, Maitra ${ }^{16}$, Keele, Neil and Joels $^{4}$, Ross and Pawlina ${ }^{20}$, Crossman $^{1}$, Krause $^{2}$ \& Mescher ${ }^{21}$, which was more than values of the present study. The reason of this difference may be due to racial variation of the study population. The mean \pm SD of weight of male gland in this study was significantly lower than that of female; this result was similar to that of McLachalan's study in London. McLachalan et al. in 1968 revealed the mean weight of pituitary gland to be $685 \mathrm{mg}$ in female and $533 \mathrm{mg}$ in male by conducting a radiological study on 50 adult post mortem sample ( 23 from male and 27 from female $)^{7}$. The present study also revealed that the mean $\pm S D$ of weight declines with age which was statistically significant $(P<0.01)$ but cannot be compared as literature or texts regarding these changes were not available.

\section{Conclusion:}

The observation and results of the present study are expected to standardize the morphology of the pituitary gland in Bangladeshi people. The weight of the pituitary gland showed gradual decreasing values with advancing age. Females have larger weight than that of males, which were statistically significant. Further studies to find out the cause of heavier glands in females \& decreasing weight of pituitary gland with advancing ages are recommended.

\section{References:}

1. Crossman AR. ed. Neuroanatomy. In: Standring S, Ellis H, Heally JC, Johnson D, Williams A, Collins P, et al. eds. Gray's Anatomy: The anatomical basis of clinical practice. $39^{\text {th }}$ ed. Edinburgh: Elsevier Churchill Livingstone 2005: 380-83.

2. Krause wJ. Hypophysis. 2010. Available athttp://web.mac.com/ wjkrause/ iweb/histology/ htm.

3. Gartner LP and Hiatt LJ. ed. Endocrine system. Colour textbook of histology: study of human structure. $2^{\text {nd }}$ ed. Philadelphia: W B Saunders Company 2001: 302-09.

4. Keele CA, Neil E, Joels N. eds. Endocrine glands. Samson Wright's applied physiology. $13^{\text {th }}$ ed. New Delhi: Oxford University Press 2004: 512 .

5. Rogers AW, Jacob S. eds. The endocrine glands. A textbook of anatomy. $1^{\text {st }}$ ed. Edinburgh: Churchill Livingstone 1992: 691-94.

6. Dietrich RB, LIs LE, Greensite FS, Pitt D. Normal MR Appearance of the Pituitary Gland in the First 2 Years of Life. AJNR 1995; 16 : 1413-19.

7. McLachlan MSF, Williams ED, Fortt RW, Doyle FH. Estimation of pituitary gland dimensions from radiographs of the sella turcica: A post mortem study. Br. J. Radiol. 1968; 41: 323-30.

8. Jacob SW, Francone CA. eds. The endocrine system. The structure and function in man. $2^{\text {nd }}$ ed. Philadelphia: WB Saunders 1970: 464-68.

9. McNicol AM. ed. Endocrine pathology. In: Macsween RNM, Whaley K. eds. Muirs textbook of pathology. $13^{\text {th }}$ ed. London: Arnold 1993: 1077-84.

10. Coupland RE. ed. Endocrine system. In: Hamilton WJ. ed. Textbook of human anatomy. $2^{\text {nd }}$ ed. London: Macmillan 1976: 482-87.

11. Kelly DE, Wood RL, Enders AC. eds. The endocrine glands. Bailey's textbook of microscopic anatomy. $18^{\text {th }}$ ed. Baltimore: Williams \& Wilkins 1984: 778-94.

12. Asa SL. Pituitary Histopathology in Man : Normal and Abnormal. Endotext.com. 2007; Available at-C:IDocuments and Settingsluserl Desktoplp.t.glptg histopthology.htm

13. Hemminki K, Forsti A and Ji j. Incidence and Familial risks in pituitary adenoma and associated tumors. Endocrine related cancer 2007;14: 103-09.

14. Akhter $\mathrm{N}$, Hassan $\mathrm{S}$ A.Subclinical hypothyroidism and hyperprolactinemia in 
infertile women: Bangladesh perspective after universal salt iodination. Int J Endo. 2009.

15. Aron DC, Findling JW, Tyrrell JB. eds. Hypothalamus and pituitary gland. In: Greenspan FS, Gardner DG. eds. Basic and clinical endocrinology. $7^{\text {th }}$ ed. New York: McGraw Hill 2004: 106-63.

16. Maitra A, Abbas KA. eds. Diseases of the endocrine system. In: Kumar V, Abbas AK, Fausto N. eds. Robbins and Cotran pathologic basis of disease. $7^{\text {th }}$ ed. New Delhi: Saunders 2004: 1156-64.

17. Tsunoda A, Okuda O, Sato K. MR Height of the Pituitary Gland as a function of age and sex: Especially Physiological Hypertrophy in Adolescence and in Climactorium. AJNR. 1997; 18: 551-54.

18. Fawcett DW. ed. Bloom and Fawcett $-a$ textbook of histology. $12^{\text {th }}$ ed. New York: Chapman \& Hall 1994; 473-88.

19. Thibodeau GA, Patton KT. eds. Endocrine system. Anatomy and physiology. $5^{\text {th }}$ ed. St.Louis: Mosby 2003: 495-501.

20. Ross $M H$, Pawlina W. eds. Pituitary gland (Hypophysis). Histology: a text and atlas with correlated cell and molecular biology. $5^{\text {th }}$ ed. Baltimore: Lippincott Williams \& Wilkins 2006: 689-97.

21. Mescher AL. ed. Junqueira's basic histology. $12^{\text {th }}$ ed. Singapore: McGraw-Hill 2010: 348-56. 